\title{
Het nationaalsocialisme en de maatschappelijke zorg vanuit de kerken 1940-1945
}

Ben Koolen

\author{
De kerels van de Winterhulp \\ Halen ook nog uit de armste stulp \\ Met trommels en fanfaar'geschal \\ Lompen en wat etensresten, \\ Saam' een afgeperste geste \\ Goedkoop liefdadigheidsgebral. \\ (Bertolt Brecht $)^{1}$
}

\begin{abstract}
De introductie van Winterhulp en de later daaraan toegevoegde Nederlandsche Volksdienst was een verleidingstruc van de nationaalsocialistische bezetter, gericht op een aanvaarding van het nieuwe regime als een menslievende organisatie. Maar veel meer dan dat ontwikkelden Winterhulp en de Nederlandsche Volksdienst zich tot instrumenten om de ideologie van het nazisme ingang te doen vinden in de Nederlandse samenleving. Hoe verhield dit zich tot het in ons land bestaande stelsel van maatschappelijke zorg ${ }^{2}$ vanuit de kerken?
\end{abstract}

\section{Oprichting Winterhulp Nederland}

Toen het besluit van Rijkscommissaris Seyss-Inquart om een stichting Winterhulp Nederland (WHN) op te richten via de pers bekend werd, begreep de meer ingewijde lezer aanstonds dat hiermee de succesvolle Winterhilfsaktion 'gegen Hunger und Kälte' van het Hitler-regime gekopieerd werd. Over de snelle opmars van Winterhilfe, die elk jaar met nieuwe records miljoenen rijksmarken inzamelde, was in de vooroorlogse Nederlandse pers met enige verbazing bericht.

Aan de oprichting van de Nederlandse variant van Winterhilfe was een nationale inzamelingsactie voor de armen voorafgegaan, georganiseerd door een Nationaal Hulpcomité (6 juli): 'aan de slachtoffers van het oorlogsgeweld moeten meubelen en kleeren gegeven worden en middelen om hun kleine bedrijven weer op gang te

1 B. Brecht, 'Winterhulp', in: Furcht und Elend des III. Reiches (vert. Th. Hoogsteder), Nederlandse Vereniging voor Volkstheater z.j. [2001].

2 Onder de term 'maatschappelijke zorg' behandel ik in deze bijdrage de armenzorg en de nietmedische gezinsbegeleiding. 
brengen', heette het. ${ }^{3}$ De actie had succes: de geschatte opbrengst bedroeg 2,5 miljoen gulden. ${ }^{4}$ Alleen al in Amsterdam werd $f 325.000$ opgehaald. ${ }^{5}$

In Seyss-Inquarts Verordening 268 van 22 oktober 1940 werd als opdracht aan de stichting Winterhulp Nederland geformuleerd: 'om den in het bezette Nederlandsche gebied levenden Nederlandschen Staatsburgers zonder aanzien des persoons hulp en ondersteuning te verschaffen'. 'De hiervoor noodige middelen worden - ongeacht de giften welke ik de stichting zal doen toekomen - door vrijwillige bijdragen in geld en goederen van de in het bezette Nederlandsche gebied levende Nederlandsche Staatsburgers verkregen' (art.1 lid 2 Verordening 268) Op 1 november werd de oprichting notarieel vastgelegd. De stichting WHN was vrijgesteld van belastingen en publiekrechtelijke lasten.

Aanstonds werd met de organisatie van de stichting een begin gemaakt. In de verordening was bepaald dat de leiding van de stichting in handen van een directeurgeneraal werd gelegd. Mr. L.J.A. Trip, president van De Nederlandsche Bank, tevens secretaris-generaal van het ministerie van Financiën, moest samen met een financiële commissie toezicht houden op het financieel beheer van de stichting.

De stichting werd opgetuigd met een ereraad op landelijk en erecommissies op provinciaal niveau. 'Alle groeperingen der Nederlandsche bevolking zullen in dezen raad vertegenwoordigd zijn, en zullen hun medewerking geven, zoodat van een breed nationaal winterhulpwerk gesproken kan worden. ${ }^{6}$ A.M. Snouck Hurgronje, secretaris-generaal van het ministerie van Buitenlandse Zaken, die als waarnemend secretaris-generaal van het ministerie van Algemene Zaken de hoogste ambtenaar in rang was, werd voorzitter van WHN. ${ }^{7}$ De commissarissen van de provincies behoorden ongevraagd tot de leden van de stichting. In feite hebben de ereraad en de erecommissies geen enkele invloed uitgeoefend.

\section{Interne organisatie}

Als directeur-generaal van WHN werd Carel Piek benoemd, een effectenmakelaar uit Dordrecht. Vóór de oorlog was hij lid geweest van de NSB, maar bij het begin ervan had hij om onduidelijke reden zijn lidmaatschap opgezegd, 'maar was wel pro-Duits en pro-nationaalsocialistisch gebleven'. ${ }^{8} \mathrm{Nu}$ werd hij als partijloos en dus neutraal naar voren geschoven. Piek koos voor een bliksemstart en wilde eind november al een eerste landelijke collecte houden. Hij slaagde er in de kortste keren in om in Den Haag een hoofdkantoor in te richten en een staf van medewerkers te formeren met drie hoofdafdelingen en een sliert aan afdelingen en

7 Snouck Hurgronje werd als voorzitter van de ereraad na zijn ontslagneming in 1941 opgevolgd door K.J. Frederiks, secretaris-generaal van het ministerie van Binnenlandse Zaken. 
onderafdelingen. De propagandamachine draaide op volle toeren en verspreidde aanplakbiljetten, persberichten en prefab-artikelen die zonder commentaar in de gelijkgeschakelde pers werden overgenomen. Per provincie kwam er een provinciaal bureau met dezelfde organisatiestructuur, nauw aanleunend tegen de provinciale griffie, onder een provinciaal directeur die de tenuitvoerlegging van de activiteiten op gemeentelijk niveau coördineerde.

De burgemeesters waren ongevraagd en ongewild als plaatselijk directeur belast met de hele organisatie van de collectes in hun gemeente. Het gemeentehuis diende tot plaatselijk bureau en onder de gemeenteontvanger berustte het beheer van de gelden. In een circulaire spoorde de secretaris-generaal van het ministerie van Binnenlandse Zaken de burgemeesters aan de benoeming tot plaatselijk directeur te aanvaarden en ook de gemeenteontvanger voor de financiële aangelegenheden vrij te maken. ${ }^{9}$ Kort daarop vroeg hij provincie- en gemeentebesturen hun ambtenaren beschikbaar te stellen 'om in hun ambtelijken tijd voor de winterhulp beschikbaar te zijn'. ${ }^{10}$

Met de ingezamelde gelden moest Nederlanders die door de winterse omstandigheden niet rond konden komen, een tegemoetkoming worden toegekend. Als doelgroepen golden 'werkloozen, oorlogsinvaliden en nagelaten betrekkingen van gesneuvelden, zij die invaliditeits- of ouderdomsrente ontvangen als ook valide arbeiders met niet toereikende verdiensten voor de wintermaanden, o.m. gedeeltelijk werkloozen'. ${ }^{11}$ Wie voor een tegemoetkoming in aanmerking wilde komen, diende zich bij de plaatselijke directeur aan te melden onder overlegging van een identiteitsbewijs met pasfoto, een loonstrookje en het trouwboekje. De burgemeester vroeg de plaatselijke politie om eventuele nadere bijzonderheden omtrent de aanvrager en diens gezin. Vervolgens stuurde hij als plaatselijk directeur de aanvragen ter beoordeling en met een aanbeveling naar de provinciale WHN-directeur, die het bedrag dat elke gemeente werd toebedeeld vervolgens vaststelde. Dat ging in de vorm van waardebonnen (van $f 0,50, f 1$ en $f 2,50$ ) waarmee de 'behoeftige' in de winkels zijn inkopen kon betalen. De waardebonnen waren erkend als wettig betaalmiddel; de winkeliers moesten deze bij enkele daartoe aangewezen banken verzilveren.

Om overdracht of verkoop aan derden te voorkomen stond op de bonnen de naam van de ontvanger vermeld; desgewenst kon de winkelier zijn klant bovendien om legitimatie vragen. Het vernederende neveneffect was natuurlijk dat degene die zo'n bon in ontvangst nam, wist wie de 'behoeftigen' in zijn clientèle waren; andere klanten zal dat ook niet ontgaan zijn.

9 Voor zover bekend weigerde één burgemeester, J.C. Haspels van Enkhuizen, elke medewerking aan Winterhulp: Romijn 2000, p. 208.

1029 oktober 1940, 12 november 1940: Reijckheyt (archief Heerlen) 062, inv.nr. 1450.

11 Richtlijnen voor de uitvoering van het Winterhulpwerk Nederland': Gemeentearchief Roermond (verder afgekort tot GAR) inv.nr. 7005-179. 


\section{Wantrouwen}

Reeds vóór de eerste actie van WHN van start was gegaan, moest Piek zich beklagen over tegenwerking vanuit de bevolking, want die liet zich niet paaien door de mooie berichten in de media. Er waren aanvallen op zijn persoon: zijn NSB-verleden, zijn riante salaris. Overal werden affiches van Winterhulp van de muren gescheurd; er circuleerden verhalen alsof alleen NSB'ers ervan zouden profiteren of dat het geld rechtstreeks naar Duitsland zou gaan. Het clandestien verspreide verzetsblad De Waarheid kopte 'Winterhulp is oorlogshulp'. ${ }^{12}$

De directeur-generaal van WHN genoot actieve steun vanuit de hoogste ambtelijke kringen. K.J. Frederiks, als secretaris-generaal van het ministerie van Binnenlandse Zaken de hoogste autoriteit van het openbaar bestuur introduceerde hem via de provinciecommissarissen bij de burgemeesters. Overal bestormden dezen hem met vragen en kritische opmerkingen. Hoe ging Winterhulp zich opstellen tegenover de bestaande caritatieve instellingen, waarop immers kort na de oprichting van Winterhulp het collecteverbod van toepassing werd verklaard: elke instantie of iedere persoon die een collecte langs de openbare weg wilde organiseren, moest daartoe vooraf toestemming krijgen van de secretaris-generaal van Justitie. Die was aanvankelijk ruimhartig verleend, maar met de intrede van Winterhulp werd een veel restrictiever beleid gevoerd. Zo verbood de bezetter de jaarlijkse collecte voor de Katholieke Universiteit, maar ook de kerstcollecte van het Leger des Heils en inzamelingen door de St.-Vincentiusverenigingen. ${ }^{13}$ WHN zelf was vrijgesteld van het collecteverbod.

Piek probeerde de burgemeesters ervan te overtuigen dat WHN alleen streefde naar vereniging en coördinatie van het bestaande caritatieve werk. In Limburg heette het: 'dit werk van barmhartigheid' wordt allerwegen gesaboteerd, er is een 'blokkade-oorlog' aan de gang waarvan de 'ongelukkige, behoeftige medemenschen' het slachtoffer waren. ${ }^{14}$ In Groningen: 'Ik ben bereid de diaconieën niet te overkoepelen. De traditie is, dat zij vrij zijn, en ik wil die traditie eerbiedigen. ${ }^{\text {'15 }}$ Winterhulp keerde zich evenmin tegen joodse behoeftigen, integendeel: 'Ras- of partijpolitieke overwegingen zullen bij de verstrekking van steun geen gewicht in de schaal mogen leggen.' Wel raadde Piek de burgemeesters veelzeggend aan niet te veel joodse collectanten de straat op te sturen. ${ }^{16}$ Niet lang daarna werden joden uitgesloten van Winterhulpsteun. ${ }^{17}$

In alle toonaarden onderstreepte Piek het Nederlandse karakter van de Winterhulporganisatie. Hij bleef benadrukken dat de inzet van zijn stichting geleid werd door het beginsel 'voor het volk, door het volk'. ${ }^{18}$ Om het algemene karakter van

\section{De Waarheid 23 november 1940.}

Het met Engeland verbonden Leger des Heils werd in 1941 verboden.

Limburger Koerier 26 november 1940.

De Standaard 29 november 1940.

Romijn 2000, p. 207.

W. ten Have, De Nederlandse Unie. Aanpassing, vernieuwing en confrontatie in bezettingstijd 1940-1941, Amsterdam: Prometheus 1999.

'Voor het Volk Door het volk' werd ook de naam van het tweewekelijkse instructieblad dat WHN vanaf februari 1941 haar leden toezond. 
'zijn' Winterhulp te onderstrepen stond hij NSB'ers niet toe in partijuniform of met partijinsignes te collecteren. Het Limburgs Dagblad onderstreepte Pieks woorden dat de WHN-inzameling 'geen bruusk einde van, of concurrentie met bestaande charitatieve organisaties' betekende. ${ }^{19}$ Maar men slaagde er nimmer in het breed gekoesterde wantrouwen tegen de bedoelingen van de bezetter met deze Winterhulp te doorbreken. Weinig overtuigd aanvaardden de burgemeesters de hun opgedrongen taak. Een steun in de rug kreeg Piek van de Nederlandsche Unie, de kort tevoren opgerichte beweging die als vaderlands alternatief voor de NSB snel tienduizenden leden wist te winnen.

Hoezeer Piek ook het tegendeel beweerde, binnen de bevolking heerste de overtuiging dat Winterhulp een zaak van de bezetter en de NSB was. Men geloofde niet in de neutraliteit van WHN, en de weigering van een bijdrage ervoer men als een verzetsdaad. Aanplakbiljetten werden van hatelijke opmerkingen voorzien, collectanten werden genegeerd of op afkeurende opmerkingen en scheldwoorden getrakteerd.

\section{Opstelling van de kerken}

Met de kerken ging de bezetter behoedzaam om. Hij was er zich van bewust dat de bedoelingen van zijn Winterhulpactiviteiten conflicteerden met de armenzorg en in bredere zin caritatieve activiteiten die tot de Bijbelse opdracht en de harde kern van het maatschappelijke engagement van de kerken behoren. Reeds in het Oude Testament is de opdracht geformuleerd om de naaste lief te hebben als jezelf (Lev. 19:18). Het Nieuwe Testament kent talrijke uitspraken over deze mensenplicht. De eerste levensopdracht is in één zin vervat: 'de Heer uw God te beminnen met heel uw hart, met heel uw ziel en met heel uw verstand en uw naaste als uzelf' (Luc. 10:27) en daarop sluit aan dat deze naastenliefde iedereen geldt, over de grenzen van het eigen volk heen, zoals het verhaal van de barmhartige Samaritaan leert (Luc. 10:30-37), ja zelfs 'bemint uw vijanden en bidt voor wie u lasteren en vervolgen' (Matth. 5:44). 'Zalig de barmhartigen, want zij zullen barmhartigheid ondervinden', luidt een van de zaligsprekingen (Matth. 5:7).

In de protestantse kerkgemeenten zijn het veelal de diakenen die de belangen van zieken en armen behartigen. In de Nederlandse katholieke traditie fungeerden de St.-Vincentius- en St.-Elisabethverenigingen als zodanig. Voor meer gestructureerde gezinsondersteuning waren er de Kruisverenigingen: het Oranje Kruis (protestants) en het Wit-Gele Kruis (rooms-katholiek), naast het neutrale Groene Kruis. Veel ziekenhuizen en vergelijkbare instellingen droegen een katholieke of protestantse signatuur met dito medisch personeel.

Regelmatige collectes langs de deuren en tijdens de kerkdiensten, versterkt door giften van particulieren en bedrijven en door erflatingen, hadden de kerken een sterke positie op dit maatschappelijk terrein verschaft. Door de introductie van Winterhulp betrad de bezetter het terrein van de traditionele armenzorg, die vanaf de negentiende eeuw vooral door levensbeschouwelijke instellingen behar- 
tigd werd; de landelijke overheid had, mede onder druk van de ingrijpende werkloosheid in de jaren dertig, voor dit doel eigen middelen ingezet. De protestantse kerken wezen van meet af aan Winterhulp af. ${ }^{20}$ Aartsbisschop de Jong uitte voorzichtige kritiek op Winterhulp, waardoor de liefdadigheid 'ondanks de goede bedoelingen' tot een staatstaak wordt gemaakt, haar specifiek christelijke karakter wordt ontnomen en wordt gelaïciseerd. ${ }^{21}$ Hij had katholieken al in oktober 1941 willen verbieden voor Winterhulp te collecteren, maar dat stuitte op verzet van de beide Brabantse bisschoppen. ${ }^{22}$

De nieuwe machthebbers waren zich bewust van het grote gezag van het episcopaat en de synode, zodat openlijke conflicten vermeden werden. Aan de vrijheid van kerkelijke gemeenschappen om binnen het kerkgebouw te collecteren raakten zij derhalve niet; publieke collectes werden de kerken en maatschappelijke organisaties echter niet toegestaan. De beleidslijn was dat elke geldinzamelingsactie die raakte aan de reikwijdte van Winterhulp Nederland uit den boze was.

Directeur-generaal Piek werd regelmatig aangevallen op het collecteverbod voor liefdadigheidswerk. Eens had hij het verleidelijke voorstel gedaan dat zulke instellingen inzamelingen zouden organiseren onder de paraplu van WHN. Dit voorstel werd meteen doorzien; de Nederlandsche Vereeniging voor Armenzorg en Weldadigheid, die een groot aantal regionale en plaatselijke initiatieven overkoepelde, ried haar leden aan niet met WHN in contact te treden. ${ }^{23}$

\section{Seizoen 1940-1941}

Met de introductie van Winterhulp moesten de burgemeesters binnen enkele weken op een voor hen onbekend terrein alle nodige voorbereidingen treffen: een organisatie uit de grond stampen, zorgen voor alle benodigdheden, collectanten werven en instrueren, en propagandamiddelen verspreiden. De meeste burgemeesters hadden dan ook niet gewacht op een introductie door de directeur-generaal van $W H N$, maar waren meteen aan de slag gegaan. Zij hadden de taken van hun plaatselijk bureau onder de ambtenaren verdeeld en waren met de besturen van de plaatselijke verenigingen in gesprek gegaan. In nogal wat gemeenten liepen zij aan tegen onverwachte obstakels. Zo waren er niet voldoende collectebussen aangeleverd, zodat hun de raad werd gegeven deze te lenen van plaatselijke organisaties. Ook suggereerde men lege cacaobussen te gebruiken of met open schalen te collecteren. ${ }^{24}$ Omdat ook de meeste provinciale bureaus nog onderbemand waren, waren de burgemeesters als plaatselijk directeur op zichzelf teruggeworpen om de problemen te overwinnen. Achteraf bleek dat heel wat aangemelde

21 Romijn 2000, p. 210.

22 De Tijd 4 mei 2005. In Noord-Brabant hadden verkiezingen uitgewezen dat de NSB relatief weinig steun genoot.

23 Utrechtsch Nieuwsblad 8 januari 1941; Instituut voor oorlogs-, Holocaust- en genocide-studies NIOD, coll. 249-0915 inv.nr. a12, a13.

24 Gemeentearchief Venlo (verder afgekort tot GAV) 228 inv.nr. 1347. 
collectanten niet waren komen opdagen, zodat hele wijken moesten worden overgeslagen.

De eerste inzamelingsactie van de stichting Winterhulp Nederland vond plaats op 29 en 30 november, hier en daar (ook) op 1 december. Het was een dubbelcollecte, zowel huis aan huis als langs de openbare weg. Om degenen die aan de deur al een bijdrage gegeven hadden te verleiden om ook bij de straatcollecte een duit in de bus te doen, werd tegen betaling van 20 cent een speldje met een lichtgevend molentje aangeboden. Spottend heette het: 'Alleen de NSB loopt met molentjes.' Ook bij alle volgende straatcollectes werd zo'n hebbedingetje aangeboden, meestal in een serie van soms wel dertien thematische afbeeldingen, wat de eventuele verzamelaar op evenzoveel maal 20 cent kwam te staan. ${ }^{25}$

Er werd ook onder het personeel van gemeentediensten, kantoren en fabrieken gecollecteerd; niet zelden stuitte dat op massieve onwil en harde verwijten. Iemand had gesuggereerd dat lagereschoolleerlingen ieder een cent zouden doneren; leerlingen van middelbare scholen konden wel een stuiver missen, dacht men. Algemeen vond men dit te ver gaan; het plan kwam dan ook niet van de grond. Later ontkende de leiding van WHN dat zij dat idee zou hebben geopperd. Landelijk werd ongeveer $f 500.000$ opgehaald, inclusief giften $f$ 881.533. ${ }^{26}$ Meteen na kerstmis, op 27 en 28 december, volgde een tweede landelijke collecte, nu alleen door inzameling op straat. Ditmaal waren speldjes met vijf verschillende sprookjesfiguren in de aanbieding. De poging om gezinnen vijfmaal 20 cent uit de zak te kloppen, lukte niet: de opbrengst, inclusief giften, viel tegen ( $f$ 482.000). Het aantal allesbehalve spontane giften van (kleinere) bedrijven was in deze periode sterk toegenomen. Met de aankondiging dat onder de gemeenten $f 800.000$ zou worden verdeeld om onder armlastige gezinnen verdeeld te worden, onderstreepte Trip, de financiële toezichthouder van Winterhulp, het nut van de inzameling.

\section{Lijstcollectes}

Om de inkomsten op te krikken lanceerde WHN een variant van de huis-aanhuiscollecte: de lijstcollecte. Elke maand zou voortaan naast de straatcollecte ook huis aan huis gecollecteerd worden met intekenlijsten: de bewoner moest zijn inleg noteren op een lijst en deze met zijn naam, adres en handtekening bevestigen. Het hielp niet als men de deur weigerde te openen; de collectanten waren uitdrukkelijk geïnstrueerd om zo vaak bij het weigerachtige adres langs te gaan totdat het standpunt van de bewoner klip en klaar duidelijk was. Dat deze handelwijze verzet opriep, lag voor de hand; velen weigerden hun naam te vermelden. Heel wat collectanten van het eerste uur haakten af en de burgemeesters slaagden er niet in voldoende vervangers te werven. De lijstcollectes bleven erg impopulair, zowel bij het publiek als bij de collectanten. In veel kleinere gemeenten vond helemaal geen lijstcollecte plaats. 
Dat er onzorgvuldig met de intekenlijsten werd omgegaan, verraadt het NSB-lijfblad waarin secretaris-generaal Huygen van de NSB zijn leden verbood de informatie van die intekenlijsten met derden te delen. ${ }^{27}$ Spoedig voorzag WHN de collectanten van lijsten waarop de namen en adressen van bewoners van diens wijk reeds waren afgedrukt, zodat de bewoner alleen zijn gift en handtekening hoefde te plaatsen; niet dat dat de bereidwilligheid bevorderde. Opmerkelijk genoeg werden niet-Nederlandse ingezetenen bij deze lijstcollecten overgeslagen: zij behoorden niet tot de doelgroep van WHN (art. 1 lid 2 Verordening) en dienden hun bijdrage te leveren aan de winterhulporganisatie in hun herkomstland. In de instructie voor de collectanten was uitdrukkelijk verboden geld in te zamelen bij leden van de Wehrmacht en andere Rijksduitsers.

\section{Giften}

Inmiddels was wel duidelijk geworden dat de frequente geldinzamelingen in de gemeenten niet de enige en achteraf gezien niet de belangrijkste inkomstenbron van WHN zouden zijn. Grote bedrijven werden 'uitgenodigd' zelf een bijdrage te storten op de rekening van WHN. Reeds in de novembermaand offerden C\&A, V\&D en Philips elk $f 50.000$, en van andere bedrijven en particulieren kwam nog eens ruim $f 50.000$ binnen. De Limburgse mijnwerkers zou met instemming van de vakbond 'de gelegenheid' worden geboden maandelijks één uurloon af te staan aan Winterhulp. ${ }^{28}$ In de loop van de maand december kwamen de kranten met het bericht dat, nog afgezien van de giften door grote bedrijven, op 3 december al $f 881.500$ binnen was, derhalve bijna $f 400.000$ aan giften van particulieren en voor het overgrote merendeel van het midden- en kleinbedrijf. ${ }^{29}$

Seyss-Inquart zelf stortte midden december $f 100.000$ in de WHN-kas. De kranten gaven niet alleen daaraan de gewenste bekendheid; periodiek verschenen lange lijsten van bedrijven die kleine of grote bedragen geschonken hadden. Het was duidelijk dat elk bedrijf, hoe klein ook, dat nu of in de toekomst in aanmerking dacht te komen van enige levering aan of een vergunning van een overheidsdienst maar beter bekendstond als begiftiger van Winterhulp. Standaard was een gift van $f 100$ het minimum. Grotere bedrijven werden geacht van hun winst een deel af te staan. De bisschoppen lieten blijken dat parochies en kloosterinstellingen niet moesten bijdragen aan de Winterhulpacties.

\section{Rekruteringsproblemen}

Bij de start van Winterhulp had de Nederlandsche Unie haar leden opgeroepen zich aan te melden als collectant. De NSB had hetzelfde gedaan en zo voerden leden van beide elkaar beconcurrerende bewegingen in de grotere gemeenten zij aan zij actie bij de collectes. Na de eerste ervaringen met de geldinzameling haakten veel collectanten echter af. De winterse omstandigheden en vooral de vaak hatelijke bejegening door het publiek hadden hen afgeschrikt, en ook de burgemeesters waren minder gemotiveerd - als ze dat al ooit waren - om zich telkens 
weer in te zetten voor de tweewekelijkse organisatie van de collectes en de daarbij behorende administratieve rompslomp. Alleen NSB'ers en andere sympathisanten met de Duitse zaak waren nog te motiveren. Om hun gemeente niet in een negatief daglicht te stellen gingen burgemeesters van kleinere gemeenten met wat ambtenaren - soms zelfs als dienstopdracht - met een collectebus de straat op. ${ }^{30}$

Landelijk werden bedrijfsleiders gemaand hun personeelsleden zonder korting op hun salaris of vakantiedagen de gelegenheid te bieden als collectant voor WHN actief te zijn. Als arbeiders afwezig waren op hun werkplek om voor WHN te collecteren, diende dit beschouwd te worden als 'geoorloofd verzuim'.

\section{Terminologische scherpslijperij}

De bestuursstructuur van de stichting was onmiskenbaar nationaalsocialistisch van aard: het gegeven dat het bestuur in één hand was gelegd, namelijk in die van de directeur-generaal, reflecteerde naadloos het nazi Führerprinzip. Heel tekenend werd die functieaanduiding begin 1941 gewijzigd in 'algemeen leider'. De terminologische verschuiving van 'stille armen' en 'behoeftige medemensen' naar 'volksgenoten' was even ideologisch bepaald: das Volk was een kernwoord in de nationaalsocialistische wereldvisie, omwille van de Germaanse stamverwantschap, waarmee joden en zigeuners uitgesloten werden. Een belangrijke zwenking voltrok zich begin 1941, toen afstand werd genomen van termen als 'naastenliefde' en 'barmhartigheid' en er op gehamerd werd dat steun aan Winterhulp een 'ereplicht' tegenover minder welvarende volksgenoten was, ook weer gebaseerd op het toebehoren aan de volksgemeenschap.

De monopolisering van de armenzorg door ingrijpen van hogerhand riep in het bijzonder in kerkelijke kringen verzet op. De protestantse kerken hadden Winterhulp van meet af aan afgewezen. Begin 1941 had aartsbisschop De Jong zich kritisch uitgelaten over Winterhulp als een ontkenning van de christelijke naastenliefde. Naastenliefde was geen staatszaak. Nochtans wilde hij niemand veroordelen die op persoonlijke titel Winterhulp een bijdrage gaf. ${ }^{31}$ Bisschop Lemmens van Roermond legde de principiële afwijzing van Winterhulp vast in een brief waarin hij het Wit-Gele Kruis en het daarmee samenwerkende Groene Kruis elke medewerking met activiteiten van Winterhulp verbood. Niet zelden werkte de parochiele geestelijkheid actief tegen. Later laakte Piek 'het gebrek aan medewerking dat zich vooral in de zuidelijke provincies demonstreerde'. ${ }^{32}$

Het centraal bureau van WHN lanceerde in een stroom van artikelen een offensief tegen de traditionele caritatieve organisaties: zij waren een dekmantel voor machinaties van confessionele, politieke of maatschappelijke stromingen met elk hun eigen verborgen bedoelingen; in bezettingstijd dient deze invloed 'geneutraliseerd' te worden. Piek wees op door het Bureau voor de Statistiek gemaakte bere-

30 Enquête onder Limburgse gemeenten Regionaal Historisch Centrum Limburg (verder afgekort tot RHCL), oktober 1941: 04.05 inv.nr. 1212.

31 De Jong 1972, p. 853; de bisschoppen hadden in een Mandement in 1936 het lidmaatschap van de NSB onverenigbaar verklaard met het katholieke geloof. Per Mandement van 1943 werd dit nog aangescherpt.

32 Nieuwe Venlosche Courant 10 januari 1942. 
keningen dat reeds vóór de oorlog van de 80 miljoen gulden aan uitgaven van de armenzorg door kerkelijke en particuliere organisaties 68 miljoen gulden afkomstig was van staatssubsidies. ${ }^{33}$ WHN markeerde het verschil tussen particuliere en Winterhulp. Winterhulp heeft niets te maken met naastenliefde; zij spruit integendeel voort 'uit de verantwoordelijkheid voor den volksgenoot en is de vervulling van den verhoogden plicht, welke ontstaat uit de grootere mate van recht en bezit', aldus een in de kranten overgenomen tekst van de propaganda-afdeling van WHN. ${ }^{34}$

Winterhulp ondervond niet alleen tegenwerking van kerkelijke zijde; Piek signaleerde dat zijn werk ook in ambtelijke kringen, 'de macht van de staatsapparatuur, ${ }^{35}$ geblokkeerd werd. Zo was secretaris-generaal Frederiks tegen de zin van Piek teruggekomen van zijn eerdere aanbeveling om provincie- en gemeenteambtenaren beschikbaar te stellen voor Winterhulp: nu bepaalde hij dat ambtenaren niet in diensttijd als collectant mochten optreden en dat collectes in overheidsgebouwen niet waren toegestaan. Ook mochten zij in diensttijd noch in uniform, noch in civiele kleding insignes dragen van de NSB of WHN. Diezelfde Frederiks bepaalde eind juli 1941 dat activiteiten van Winterhulp niet ten laste mochten komen van de gemeentelijke begroting.

\section{De Nederlandsche Volksdienst}

Om het staatsmonopolie inzake welzijnswerk kracht bij te zetten werd in juli 1941 de Nederlandsche Volksdienst (NVD) opgericht. Als zijn doelstelling gold: 'de verzorging van alle Nederlanders uit een oogpunt van zorg voor het volk en voor de welvaart, zoomede overeenkomstige opgaven'. 'De NVD is dus niet een instelling die voor extraatjes zorgt, zooals zoovele van de z.g. liefdadigheidsinstellingen van voorheen dat deden, die met een groot gebaar iets van de tafels der rijken afschoven naar de arme stakkers. De NVD kent alleen zelfbewuste, fiere volksgenooten. ${ }^{36}$ De NVD trad in de plaats van zo'n honderdvijftig opgeheven caritatieve instellingen, waarvan de vermogens naar de dienst vloeiden. Zijn belangrijkste inkomstenbron waren echter de subsidies van de Duitse moederinstelling, de National-Sozialistische Volkswohlfahrt, die vele miljoenen bedroeg. ${ }^{37}$ In de ogen van secretaris-generaal Frederiks was de NVD louter een mantelorganisatie van de NSB. ${ }^{38}$ Van deze NVD maakte Winterhulp Nederland voortaan deel uit; Piek werd algemeen leider van beide organisaties.

Was Winterhulp bedoeld voor incidentele hulp, de Volksdienst diende structureel bij te dragen aan de verhoging van het welvaartsniveau 'door gezondmaking van gezinnen', zoals in een voorlichtingsbrochure werd geformuleerd. ${ }^{39}$ De bezetter betrad met dit nieuwe initiatief het terrein van in het bijzonder de per denominatie actieve Kruisverenigingen. De Volksdienst ging zich in het bijzonder bezighou- 
den met kraamzorg, bijstand aan probleemgezinnen, huishoudelijke hulp aan grote gezinnen, schooltandverzorging en gezondheidszorg. Ook verstrekte hij met ingezamelde kleding en meubilair hulp in natura. De Volksdienst zette zich ook in bij bombardementen en bomaanslagen, ten behoeve waarvan $f 87.000$ werd uitgekeerd.

De uitzending van kinderen en moeders met veel kinderen naar rustoorden in binnen- en buitenland was een geliefd thema van de NVD. In zijn eerste werkingsjaar zond de dienst 13.400 kinderen naar tehuizen en pleeggezinnen, 11.000 van hen naar Duitsland; daar leerden ze de taal en kwamen in aanraking met het leven in nationaalsocialistische zin. Ook 750 moeders kregen gelegenheid op adem te komen, maar de meesten van hen bleven in Nederland. In 1943 waren deze aantallen opgelopen tot 20.756 uitgezonden kinderen en 1692 moeders. ${ }^{40}$

Ook stimuleerde de NVD de 'eenpansmaaltijden'. Dat Eintopfessen was in Duitsland ingeburgerd als een symbool van Germaanse volksverbondenheid. Grote groepen werden bijeengebracht rond een eenvoudige, doch voedzame stamppot. Hun werd een bijdrage gevraagd die ten goede kwam aan Winterhulp. SeyssInquart had in december 1940 al aangezeten aan een Eintopfessen van de Duitse gemeenschap in Den Haag, en kort daarna was in Heerlen door de NSNAP samen met Akense partijvrienden een soortgelijke bijeenkomst gehouden.

Om Winterhulp ook in de zomerperiode onder de aandacht van de bevolking te houden organiseerde WHN een loterij. Zes miljoen loten in zes series moesten aan de man gebracht worden. Er moeten heel wat loten onverkocht zijn gebleven - er is sprake van een kwart miljoen loten -, want in oktober konden bedrijven deze voor een zacht prijsje opkopen om de personeelsleden nog een kans te geven bij de natrekking (premietrekking) in december. ${ }^{41}$

\section{Opbrengst seizoen 1940-1941}

De financiële toezichthouder maakte de resultaten bekend van het eerste werkingsjaar van WHN. Het totaalresultaat kwam uit op 7,2 miljoen gulden. De stroom aan giften in geld en natura bleek het leeuwendeel uit te maken: $f$ 6,1 miljoen; de collectes en de loterij leverden samen ruim 1 miljoen gulden op. De eerste collecte had inclusief plaatselijke en provinciale giften volgens de persberichten nog $f 500.000$ opgeleverd, maar de eerstvolgende, de kerstcollecte, nog maar de helft. In januari haalde men $f 420.000$ op, in de maand erop slechts $f$ 190.000. Ontegenzeggelijk was in de maandelijkse berichtgeving de opbrengst van de collectes flink opgehoogd met giften. Aan uitkeringen werd $f 5.179 .000$ beschikbaar gesteld. Dat kwam per persoon/gezin neer op gemiddeld $f 7,82$.

\section{Seizoen 1941-1942}

Op een grote startbijeenkomst op 15 oktober 1941van het tweede seizoen van Winterhulp hield Frederiks als voorzitter van de ereraad de Winterhulporganisa- 
tie een spiegel voor. Hij signaleerde een al te manifeste zelfverzekerdheid bij de pleitbezorgers van Winterhulp. Men kon de maatschappelijke tegenstellingen maar beter niet verdoezelen, want 'onloochenbaar nu is in ons volk een stemming die Winterhulp Nederland op zijn zachtst uitgedrukt niet welgezind is' . ${ }^{42}$

Ook vroeg Frederiks aandacht voor de zware belasting die op de schouders van de burgemeesters was gelegd. De druk op de gemeenten noemde hij onverantwoord zwaar. Al had hij er aanvankelijk mee ingestemd, nu deelde hij Piek mee dat er een einde moest komen aan de inzet van gemeenteambtenaren. ${ }^{43}$ Deze voor het werk van WHN ingrijpende beslissing werd niet overal aanstonds opgevolgd, maar leidde op den duur tot een terugval in de gemeentelijke betrokkenheid bij Winterhulp.

De secretaris-generaal stond op dat moment onder grote druk vanwege tientallen ontslagbrieven van burgemeesters die weigerden nog langer onder het heersende regime hun ambt te vervullen. De op 11 augustus 1941 door de Rijkscommissaris Seyss-Inquart getekende, op 1 september van kracht geworden Verordening 152 had de staatkundige structuur van ons land ingrijpend in nationaalsocialistische zin gewijzigd: in plaats van de democratische bestuursstructuren was het Führerprinzip leidraad geworden. Op gemeentelijk niveau werden de gemeenteraad en het college van burgemeester en wethouders 'te rusten gelegd' en kreeg de burgemeester en hij alleen het beslissingsrecht ten aanzien van alle zaken van zijn gemeente, onder toezicht van de even autocratisch fungerende commissaris van de provincie. Raadsleden en wethouders verloren hun meebesturende rol, maar bleven, naar believen van de burgemeester, in adviserende zin betrokken. ${ }^{44}$ De plaatselijke of regionale leider van de NSB werd de informele sparringpartner van de burgemeester nieuwe stijl. Overal in het land gaven burgemeesters er de brui aan, maar nergens zo manifest als in Limburg: de burgemeesters van Kerkrade, Maastricht, Sittard en Venlo en die van zo'n veertig kleinere gemeenten vroegen in het najaar 1941 ontslag.

$\mathrm{Na}$ vergeefse pogingen van de secretaris-generaal van Binnenlandse Zaken om hen van gedachten te doen veranderen, kregen de burgemeesters met onmiddellijke ingang oneervol ontslag met vervallenverklaring van wachtgeld- en pensioenrechten. Hun plaatsen werden aanstonds opgevuld door NSB'ers of althans met het nationaalsocialisme sympathiserende personen, de meesten zonder bestuurlijke ervaring. Vooral in kleinere gemeenten moeten zij zich eenzaam hebben gevoeld, want daar waren nauwelijks geestverwanten om hun werk te ondersteunen. De nieuwe mandatarissen staan voor 'een muur van wantrouwen, haat en misverstand', aldus commissaris De Marchant bij de installatie van de NSBburgemeester van Beek. Vaak stuitte de nieuwe dorps-Führer op een afstandelijke,

42 Integrale tekst in Frederiks, Op de bres, p. 89-91. Utrechtsche Courant 16 oktober 1941.

43 Nieuwsblad van het Zuiden 27 augustus 1941.

44 Verordeningenblad voor het bezette Nederlandsche gebied, nr. 33, 12 augustus 1941. In gesprekken met 'goede' burgemeesters adviseerde de secretaris-generaal van Binnenlandse Zaken deze 'degradatie' van wethouders te ignoreren en zo veel mogelijk collegiaal bestuurlijk overleg met hen te blijven voeren: D. Hillenius, 'Mr.Dr. K.J. Frederiks (1881-1961)', in VNG-Magazine 2001, 51/52, p. 51. 
zo niet weigerachtige omgeving. De ambtenaren van de secretarie deden lijdzaam wat de nieuwe burgemeester hun opdroeg.

Bij hun installatie beklemtoonden NSB-burgemeesters steevast dat zij Winterhulp tot hun prioriteiten rekenden. Verschillenden gaven aan dat bedrijven die niet tot de beneficiënten van Winterhulp behoorden, niet mochten rekenen op leveranties aan de gemeente of coulante behandeling van een verzoek. Aldus burgemeester Van Vloten van Delft, maar ook die van Sneek, Maastricht, Sittard en Venlo zelf geen NSB'er. ${ }^{45}$ De burgemeester van Maastricht voegde hieraan toe dat onder de bedoelde leveringen ook die aan openbare scholen, musea en ziekenhuizen vielen. Burgers wier namen niet op de collectelijsten voorkwamen, mochten evenmin rekenen op enige coulance van het gemeentebestuur; en bij voorkomende collectieve werkinzet wachtten hen de minder aangename opdrachten.

\section{Tweede cyclus van de inzamelingen}

De werkwijze van het eerste jaar van WHN werd ook in het volgende werkingsjaar toegepast. Wederom waren er elke maand een lijst- en een straatcollecte met verkoop van speldjes voorzien, en bovendien een zomerloterij. Daarnaast waren plaatselijk allerlei activiteiten ontwikkeld ten bate van WHN. NSB-afdelingen in de grotere steden voelden zich nu sterk genoeg om eenpansmaaltijden - feestjes van partijgenoten en vertegenwoordigers van de bezettende macht - te organiseren.

\section{Organisatorische veranderingen}

De lente 1942 bracht het verrassende bericht van het ontslag van Carel Piek. De Rijkscommissaris zwaaide hem veel lof toe voor zijn inzet en stelde een benoeming op een andere post in het vooruitzicht, maar Pieks vertrek geschiedde niet op eigen verzoek. ${ }^{46}$ Zijn voortdurende pogingen om de Winterhulporganisatie te behoeden voor een NSB-stigma hadden zich tegen hem gekeerd. De NSB voelde zich inmiddels krachtig genoeg om nu openlijk het heft in eigen hand te nemen. Op 1 juni 1942 trad Frederik van Vloten als algemeen leider van de NVD en WHN aan, een doorgewinterde NSB'er die de beide functies aanvankelijk combineerde met die van burgemeester van Delft. ${ }^{47}$ Tot zijn eerste besluiten behoort het verlof aan NSB-leden om te collecteren in partijuniform.

\section{Opbrengst seizoen 1941-1942}

In het seizoen 1941-1942 werden wederom zes straat- en evenveel lijstcollectes gehouden, plus een zomerloterij. De opbrengst was in vergelijking met het vorige

Circulaire landelijk bureau WHN, 12 november 1941: RHCL 04.05 inv.nr. 1209: 'Een totale onttrekking aan de sociale plichten beteekent zichzelven uit de gemeenschap te sluiten'; De Telegraaf 16 november 1941.

46 Piek kreeg wat onbeduidende functies ten behoeve van de Nederlandse Oostcompagnie en later van de Germaanse SS, en nadien was hij in Zuid-Frankrijk gedetacheerd voor de behartiging van Nederlandse bewoners. In november 1944 werd hij benoemd tot secretaris-generaal van het Nederlandse Rode Kruis.

47 In augustus 1942 nam Van Vloten ontslag als burgemeester van Delft. 
seizoen aanzienlijk hoger, namelijk $f$ 10.096.076. ${ }^{48}$ Collectes en giften brachten volgens WHN $f$ 7.778.809 op, giften in natura beliepen een waarde van $f$ 740.000, de loterij leverde $f 1.300 .000$ op.

Opmerkelijk genoeg pretendeerde WHN dat de resultaten van de collectes in vergelijking met de eerste werkperiode gelijk zouden zijn gebleven. ${ }^{49}$ Volgens De Jong was van een gelijkblijvende opbrengst van de collectes geen sprake: zij zouden slechts $f$ 1,6 miljoen hebben opgeleverd, tegen $f$ 2,4 miljoen in de eerste periode. ${ }^{50}$ Ook hier wreekt zich de onbetrouwbaarheid van de door WHN opgegeven baten van de collectes. Dat die collecteopbrengsten teleurstellend laag waren, mag ook hieruit worden afgeleid dat de provinciale bureaus kennelijk was opgedragen af te zien van het bekendmaken van de resultaten per gemeente. De hoogte van de toekenning van waardebonnen per gemeente werd nog wel via de pers wereldkundig gemaakt. Aan uitkeringen werd aan de gemeenten $f 9.563 .000$ overgemaakt. Dit bedrag kwam ten goede aan ongeveer 750.000 personen, wat neerkomt op een gemiddelde bijdrage van $f 50$ per gezin.

De NVD zond 9407 kinderen op vakantie, van wie 8423 naar Duitsland; 744 moeders werden uitgezonden, maar slechts 150 naar Duitsland. ${ }^{51}$

\section{Seizoen 1942-1943}

De bekende cyclus van straat- en huis-aan-huiscollectes werd ook in dit seizoen gevolgd en vond zijn afsluiting andermaal in een zomerloterij. Gelijktijdig met de loterij organiseerde de NVD eind juli en eind augustus eigen collectes. ${ }^{52}$

As nieuwigheid stond een 'Dag van de Politie' op het programma, met in uniform collecterende agenten, marechaussee en brandweerlieden. In de leiding van de meeste stedelijke politiekorpsen waren inmiddels NSB'ers benoemd en WHN mocht dan ook verwachten dat 'de politieman als vriend en helper van het volk'53 per dienstorder massaal de straat op zou gaan. Dat kon alleen maar leiden tot een flinke verhoging van de al tijden kwakkelende collecteopbrengsten. Als stok achter de deur werd aangekondigd dat weggebruikers zonder collectespeldje moesten rekenen op een extra strenge controle van hun voertuig. De Dag van de Politie had het gewenste resultaat: $f 92.799$ werd bijgeschreven op het conto van WHN. ${ }^{54}$ In veel steden was met optochten van politie, marechaussee en brandweer door de stad en 's middags een eenpansmaaltijd voor kinderen uit armlastige gezinnen cachet aan dit initiatief gegeven. ${ }^{55}$ In Venlo had men bedacht deze dag op te luisteren met een optocht met muziek van alle schoolkinderen. Van de vijftien lagere scholen weigerden er twaalf hieraan mee te werken: in gezamenlijk overleg deelf 9.829.058.

Limburgs Dagblad 23 oktober 1942.

De Jong 1975, p. 492-493. Hij berekende de opbrengst van de loterij op $f 1,3$ miljoen.

Het Volk 14 oktober 1942.

GAV inv.nr. 38, 137.

Het Volk 14 november 1942.

Het Volk 24 december 1942.

Limburger Koerier 16 november 1942. 
den deze bijzondere scholen mede dat medewerking 'buiten hun competentie' lag en uitsluitend tot de verantwoordelijkheid van de ouders behoorde. Toen duidelijk werd dat ook de Nationale Jeugdstorm acte de présence zou geven en (vooral) dat de maaltijd bedoeld was voor kinderen uit 'minder bedeelde gezinnen', haakten heel wat van de nog geen vijftig overgebleven kinderen alsnog af. ${ }^{56}$

Ook heel wat politiemensen weigerden hieraan deel te nemen. De Roermondse burgemeester vernam van zijn politiecommissaris dat niemand uit het korps bereid was als collectant op te treden: de politieagent wilde niet als bedelaar optreden bij personen die hij eerder had terechtgewezen of bekeurd. ${ }^{57}$ De NSBgezinde secretaris-generaal van Justitie verbood later elke inzet van politiepersoneel, want hun deelname had 'dikwijls tot onaangenaamheden geleid die het aanzien van de politie schaadde'. ${ }^{58}$

De quasi vrijwillige bijdrage van werknemers in de vrije sector ad één procent van het maandloon was 'met instemming van de vakbond' al in 1940 ingevoerd. In het voorjaar 1943 beproefde men deze maatregel ook bij de ambtenarij ingang te doen vinden. De ontvangst ervan in de gemeente Hoensbroek lijkt mij exemplarisch te zijn: van de 38 ambtenaren en werklieden van het gemeentehuis wensten er achttien zelfs niet voor 'gezien' te tekenen toen de burgemeester de circulaire ter inzage had gegeven; het gehele politiepersoneel weigerde en bloc. Als oogst berichtte de burgemeester het provinciale bureau dat één ambtenaar had ingestemd met het gevraagde loonoffer. ${ }^{59}$

De steeds prominentere rol van de NSB werd weldra overschaduwd door het besef dat de positie van Hitlers Duitsland aan het wankelen was geraakt. Eind februari 1943 werden de contouren van de bittere nederlaag bij Stalingrad duidelijk, en enkele weken later stortte het Duitse front op de Noord-Afrikaanse kust ineen. Ook binnenslands vertoonde het gewapend verzet tegen de bezetters een nieuwe kracht.

Het bombardement van Rotterdam (31 maart 1943), waarbij honderden doden vielen ten gevolge van een deels mislukte Brits-Amerikaanse luchtaanval op het havengebied, werd aanstonds door de NVD aangegrepen om ten bate van de slachtoffers een landelijke inzameling van huisraad, kleding, schoeisel en beddengoed en een straat- en huis-aan-huiscollecte (10-19 april) te houden. ${ }^{60}$ Er volgde geen informatie over de opbrengst ervan. ${ }^{61}$

\section{Opbrengst 1942-1943}

Weer waren de opbrengsten exponentieel toegenomen, nu tot een totaal van $f 13$ miljoen gulden. Opmerkelijk is het grote aandeel giften in natura: $f 2,5$ miljoen. Aan collectes en vooral giften werd $f 8.228 .000$ binnengehaald, terwijl de loterij

60 Brief van het provinciaal bureau aan burgemeesters en buurtschapleiders, 7 april 1943: Rijckheyt 062 inv.nr. 1460.

61 De Telegraaf 28 juli 1943 meldde een onwaarschijnlijk hoge opbrengst van ruim 2 miljoen gulden. 
$f$ 2,4 miljoen opleverde. ${ }^{62}$ Bedrijven namen met hun bijdragen ter hoogte van $f 5$ miljoen het leeuwendeel van de inkomsten voor hun rekening. Bij dit alles valt een overheveling door WHN van geld ( $f$ 900.000) en goederen (voor $f 1,3$ miljoen) aan de NVD op. Aan waardebonnen werd $f 10.646 .000$ uitgekeerd, waarvan $f$ 7.253.000 in de vorm van waardebonnen, $f$ 2.468.000 in natura en $f 925.100$ aan voedselpakketten.

De NVD had bijna 21.000 kinderen op vakantie gestuurd, van wie 16.000 naar Duitsland. Ook 1512 moeders waren uitgezonden, van wie er 1380 in Nederland bleven. ${ }^{63}$

\section{Seizoen 1943-1944}

Vanaf oktober tot en met maart werd wederom het bekende program van elke maand een lijst- en een straatcollecte met de speldjesverkoop, met als afsluiting de zomerloterij. De Dag van de Politie verdween uit het programma. ${ }^{64}$

Het landelijk bureau verspreidde tot en met april 1944 regelmatig persberichten met het saldo van de - sterk teruglopende - giften. De lijsten met de donateurs bleven achterwege. De grote concerns mochten, wellicht vanwege de penibele militaire situatie, kennelijk afzien van hun megabijdragen. Ook over uitkeringen aan gemeenten werden geen mededelingen meer gedaan.

De PTT deed nog een duit in het zakje door in de lente van 1944 een serie van vijf toeslagzegels uit te geven ten bate van Winterhulp en de Nederlandsche Volksdienst. De totale opbrengst uit de toeslag was anderhalf miljoen gulden. De zegels zijn nauwelijks gebruikt voor het frankeren van poststukken; 'het overgrote deel werd gekocht met speculatieve doeleinden' ${ }^{65}$

De financiële controle van het financieel beheer van WHN en de NVD was op bevel van hogerhand overgegaan van De Nederlandsche Bank naar de Rekenkamer. Volgens de illegale pers had de Rekenkamer deze opdracht nochtans geweigerd vanwege de bepaling dat zij alleen de inkomsten en niet de uitgaven mocht beoordelen. ${ }^{66}$ Hoe het ook zij, over het seizoen 1943-1944 werd geen financiële verantwoording meer afgelegd.

\section{Seizoen 1944-1945}

Als gebruikelijk kondigde Van Vloten eind augustus een nieuw seizoen van geldinzamelingen ten gunste van Winterhulp aan. Inmiddels had de Nederlandsche

62 Volgens De Jong 1975, p. 492-493, was het aandeel van de collectes f 1,7 miljoen, derhalve aan giften $f$ 5,3 miljoen.

63 Het Vaderland 2 oktober 1943.

64 Rondschrijven over de Dag van de Politie 11 oktober 1943: GAV 228 inv.nr. 348.

65 G. Holstege \& J. Vellekoop, Achtergronden van de Nederlandse postzegelproductie tijdens de Duitse bezetting in de Tweede Wereldoorlog, Rotterdam 1990, p. 93-99, citaat op p. 99.

Trouw 27 maart 1944. 
Volksdienst in de zomermaanden een eigen straat-, lijst- en huis-aan-huiscollecte georganiseerd, met als thema 'Voor moeder en kind'. ${ }^{67}$

\section{Roemloos einde}

De snelle opmars van de geallieerde troepen hadden begin september 1944 vooral onder de hogere Duitse beambten en NSB'ers een ware paniek veroorzaakt. Op de doorsnee-Nederlander had het een tegengesteld effect: vooral in de Hollandse steden brak een euforie los om de aanstaand verwachte bevrijding. De Duitse bezettingsmacht stond perplex en menig kopstuk van de NSB nam ijlings de benen en trok naar het oosten, richting Duitsland. Ook Frederik van Vloten was met zijn vrouw weggevlucht voor de verwachte volkswoede. ${ }^{68}$

Meteen kwam er een reactie van de achtergebleven diensthoofden van het landelijke bureau van de NVD en WHN: 'In tegenstelling tot geruchten worden alle werkzaamheden voor zover de dienst dat toelaat voortgezet. Van liquidatie is geen sprake.' Aanstonds was een viermanschap benoemd dat de leiding over de organisatie op zich zou nemen. ${ }^{69}$ Desondanks werd Dolle Dinsdag, 5 september 1944, de doodsteek voor Winterhulp Nederland en de Nederlandsche Volksdienst. Mussert op zijn beurt nam zijn maatregelen. Tot degenen die als partijlid werden geschorst, behoorde ook Van Vloten.

Het viermanschap ging vanaf november tot en met maart 1945 in het Nederland boven de grote rivieren weer straatcollectes organiseren: in elk geval een huisaan-huiscollecte op 4 tot en met 6 januari te Haarlem, een soortgelijke inzameling op 1 tot en met 3 maart in Friesland, en midden maart een straatcollecte in Apeldoorn. ${ }^{70}$ Duidelijk is dat men er niet in slaagde weer de nodige collectanten op de been te brengen; het lijkt er veeleer op dat nog slechts hier en daar enkele diehards de straat op kwamen en dat hun pogingen algemeen genegeerd werden. Wel werd nog begin 1945 een oproep gelanceerd om verzoeken om uitkeringen in te dienen. Met enige vooruitziendheid bepaalde het WHN-hoofdbureau dat winkeliers ontvangen waardebonnen vóór 28 februari dienden te verzilveren. ${ }^{71}$

\section{Bevrijde gebieden}

De voortschrijdende bevrijding van Zuid-Nederland betekende daar vanzelfsprekend het einde van WHN en de NVD. Het militair gezag dat de staatsmacht in handen had genomen, liquideerde aanstonds de vertegenwoordigingen van WHN en de NVD en legde beslag op hun bezittingen als vijandig vermogen, met als eerste de Limburgse kassen van WHN. Vanuit Londen reageerde de voorlopige regering-Gerbrandy op de ineenstorting van de beide hulpinstanties door in novem-

67 Arnhemsche Courant 24 augustus 1944

68 De medewerkers van het hoofdkantoor van NVD, toen gevestigd in Nijmegen, keerde Van Vloten vóór zijn vertrek drie maanden salaris uit: De Jong, deel 10a, p. 199.

69 Het Volk 7 september 1944.

70 Het Volk 23 december 1944; Graafschap-bode 20 februari 1945; Nieuwsblad voor Friesland 21 februari 1945; Nieuwe Apeldoornsche Courant 28 maart 1945.

71 Utrechtsche Courant 18 januari 1945. 
ber 1944 de Stichting Volksherstel op te richten, waaraan alle bezittingen van WHN en de NVD werden toevertrouwd. ${ }^{72}$

\section{Zuivering}

Meteen na de bevrijding maakte het militair gezag ernst van de internering van burgemeesters en andere personen die van collaboratie verdacht werden. De opgesloten personen maakten er een bittere tijd door; pesterijen door bewakers waren aan de orde van de dag en ontegenzeggelijk werden er mensenrechten geschonden.

De geïnterneerden, maar ook burgemeesters die tijdens de oorlog gewoon waren blijven functioneren, moesten zich voor een zuiveringscommissie verantwoorden. In de voorbereiding daarvan had minister Beel van Binnenlandse Zaken in september 1945 de criteria geformuleerd waarop de gedragingen van bestuurders en ambtenaren tijdens de bezetting zouden worden beoordeeld. Hij noemde er vier: door zich in woord en daad te scharen aan de zijde van de vijand, door blijk te geven van een nationaalsocialistische geestesgesteldheid, ook al was hij geen lid van de NSB geweest, door in hun houding aan de Nederlandse zin voor recht en vrijheid vreemde opvattingen te propageren, en ten slotte door in ernstige mate tekort te schieten in het betrachten van de juiste houding in verband met de bezetting. Wie zich daaraan schuldig had gemaakt, wachtte oneervol ontslag met verlies van pensioenrechten. Daarbij werd gesteld dat medewerking aan activiteiten als die van WHN, op zichzelf genomen niet viel onder de vier genoemde criteria, hoewel duidelijk is dat betrokkene onjuist had gehandeld; het gevolg was ongevraagd eervol ontslag met behoud van pensioenrechten. ${ }^{73}$

\section{Tot besluit}

Al spoedig werd duidelijk dat de Duitse bezetter zichzelf met de introductie van Winterhulp, gevolgd door de Nederlandsche Volksdienst. een monopoliepositie wilde verwerven op het gebied van de maatschappelijke zorg. In tegenstelling tot het verenigingswezen, dat verboden werd als het niet het kielzog van de NSB koos (april 1941), ging de nieuwe machthebber behoedzaam om met de bestaande levensbeschouwelijke gemeenschappen. Maar zijn beleid was er wel van meet af aan op gericht hun invloed te breken. Daartoe frustreerde de bezetter de financiele voeding vanuit de samenleving voor deze, onder meer kerkelijk geïnspireerde, particuliere caritatieve instellingen en ging hij met de oprichting van de Nederlandsche Volksdienst de concurrentie aan met de bestaande caritatieve instellingen. Het bestaande stelsel van sociale zorg in Nederland werd echter niet verboden en wist zich door kerkelijke en andere maatschappelijke fondsen te handhaven.

73 Van Vloten werd in 1947 tot vier jaar gevangenisstraf met aftrek van voorarrest veroordeeld; Piek kreeg acht jaar, hetgeen in cassatie werd bevestigd. Frederiks' handelwijze resulteerde in ongevraagd eervol ontslag. 
Winterhulp was een eerste stap om de Nederlandse samenleving in nationaalsocialistische zin te herstructureren. De strategie daartoe van het regime onder SeyssInquart werd door kerkelijke en maatschappelijke leiders - de synode van de hervormde kerk, de bisschoppen en uiteindelijk ook de initiators van de Nederlandsche Unie - na enkele maanden, meer in het bijzonder in het begin van 1941, doorzien. Van toen af aan stelden zij zich daartegen te weer. Tot een openlijke confrontatie tussen kerken en de bezettende macht kwam het echter niet. Het gros van de bevolking had zich spontaan al eerder afkerig getoond van de sirenenzang van de handlangers van het nieuwe bewind. 